\title{
A case of Pulmonary Hamartoma
}

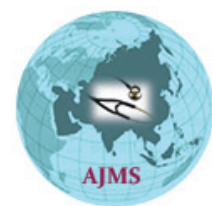

Sir,

Pulmonary hamartoma is a rare benign nodular lesion of the lung parenchyma. The patients are mostly males and present in their sixties. They are usually asymptomatic or may present with symptoms like dyspnoea, chest pain or hemoptysis. Because of its relatively asymptomatic nature, the lesion is often diagnosed incidentally.

A 67 year old male, retired government officer, presented with history of occasional cough and hemoptysis (5 to $10 \mathrm{ml}$ ) for the past 3 months. He is a non-smoker with no history of dust exposures. He is not a known case of any comorbid condition and is not on any regular medications. There was no history of fever, chest pain, dyspnoea or weight loss. His vitals and systemic examinations were normal. His blood investigations and ECG were normal. Chest Xray showed a doubtful calcified lesion in the left upper zone (Figure 1). CT thorax was taken for confirmation, which showed irregular popcorn like calcified lesion in the left upper lobe (Figure 2). CT guided biopsy was taken and histopathological examination revealed fibromyxoid stroma, epithelial cells and bone tissue; confirming the diagnosis of hamartoma. He was advised surgical excision of the lesion; but the patient and his relatives were not willing for intervention.

Albrecht described pulmonary hamartoma in 1904 as a tumour-like malformation comprising of disorganized mixture of epithelial and mesenchymal elements. Hamartochondroma, chondromatous hamartoma, adeno-chondroma and mesenchymoma are the other nomenclatures of the lesion..$^{1-3}$ These lung lesions arise from embryological rests that are present from fetal life, and are rarely visible before adulthood. ${ }^{2,4}$ They comprise of disorganized mixture of epithelial and mesenchymal components like of fibromyxoid stroma, cartilage, adipose tissue, smooth muscle cells and respiratory epithelium. Bone and bone marrow may also be present. ${ }^{4,5}$ Chest radiography shows a coin lesion or popcorn like calcification. They are usually small, well demarcated solitary lesions (1 to $6 \mathrm{~cm}$ in size) and mostly seen at the peripheries. Central hamartomas may

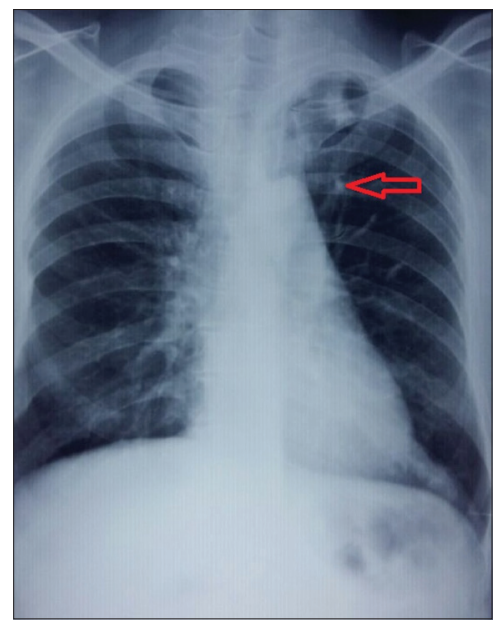

Figure 1: Chest Xray showing a calcified lesion in the left upper zone

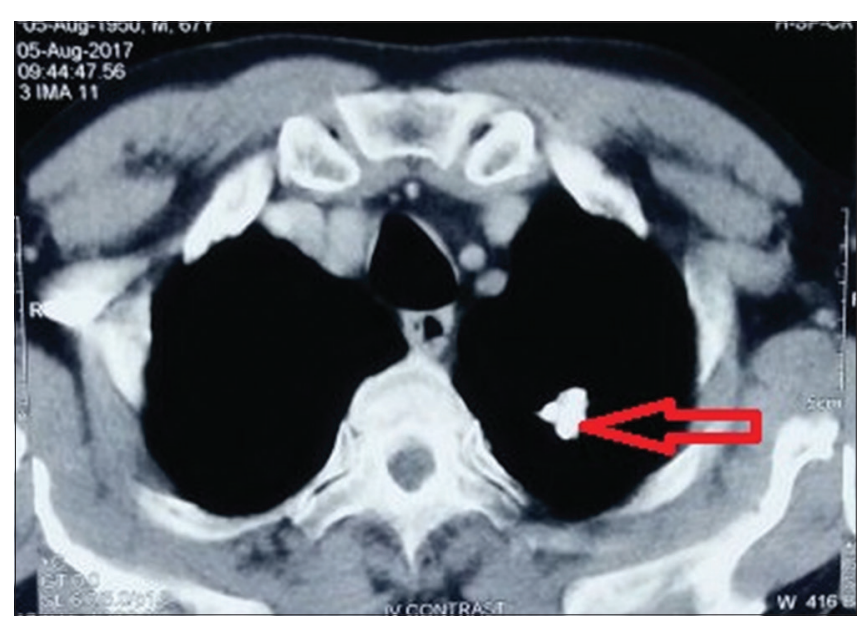

Figure 2: CT thorax showing irregular popcorn like calcific lesion in the left upper lobe

cause bronchial obstruction resulting in atelectasis and pneumonitis. ${ }^{1,2}$ Histopathological examination of the fine needle aspirate specimen is characterized by fibromyxoidstroma, adipose tissue, cartilage, bronchial cells, and 
rarely bone marrow. ${ }^{3}$ Pulmonary hamartomas may not require any treatment. However, symptomatic cases, large lesions or rapidly growing lesion requires surgical interventions like enucleation, segmental resections or even lobectomy. ${ }^{2,6}$

Key words: Pulmonary hamartoma, Hemoptysis, Fibromyxoid stroma

\section{Mele Chelakkoth Sabir ${ }^{1}$, Robin George Manappalli|2}

${ }^{1}$ Consultant, Department of Pulmonary Medicine, Baby Memorial Hospital, Calicut, Kerala 673004, India, ${ }^{2}$ Consultant, Department of Internal Medicine, Baby Memorial Hospital, Calicut, Kerala 673004, India

Address for correspondence: Robin George Manappallil, Consultant, Department of Internal Medicine, Baby Memorial Hospital, Calicut, Kerala 673004, India. Tel: 0091-8547753396. E-mail: drrobingeorgempl@gmail.com

\section{REFERENCES}

1. Jacob S, Mohapatra D and Verghese M. Massive chondroid hamartoma of the lung clinically masquerading as bronchogenic carcinoma. Indian J Pathol Microbiol 2008; 51:61-62.

2. Sinner WN. Fine-needle biopsy of hamartomas of the lung. AJR Am J Roent Genol 1982; 138:65-69.

3. Hummel P, Cangiarella JF, Cohen JM, Yang G, Waisman J and Chhieng DC. Transthoracic fine-needle aspiration biopsy of pulmonary spindle cell and mesenchymal lesions: a study of 61 cases. Cancer 2001; 93:187-198.

4. Hughes JH, Young NA, Wilbur DC, Renshaw AA and Mody DR. Fine-needle aspiration of pulmonary hamartoma: a common source of false-positive diagnoses in the College of American Pathologists Interlaboratory Comparison Program in Nongynecologic Cytology. Arch Pathol Lab Med 2005; 129:19-22.

5. Otani Y, Yoshida I, Kawashima O, Yamagishi T, Ishikawa S, Ohtaki A, et al. Benign tumors of the lung: a 20-year surgical experience. Surg Today 1997; 27:310-312.

6. de Rooij PD, Meijer S, Calame J, Golding RP, van Mourik JC and Stam J. Solitary hamartoma of the lung: is thoracotomy still mandatory? Neth J Surg 1988; 40:145-148.

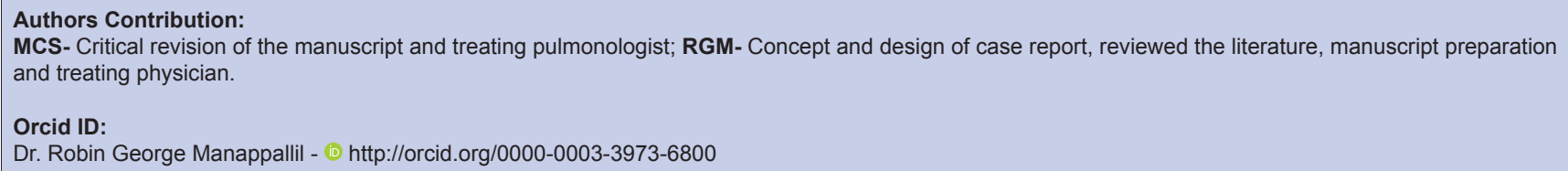

